\title{
New records of tricolored bats (Perimyotis subflavus) in Colorado, with first evidence of reproduction
}

\author{
Rick A. Adams ${ }^{1, *}$, Burton Stoner ${ }^{2}$, Donna Nespoli ${ }^{3}$, and Sarah M. Bexell ${ }^{4}$ \\ ${ }^{1}$ School of Biological Sciences, University of Northern Colorado, Greeley, CO 80639 \\ ${ }^{2}$ City of Boulder Open Space and Mountain Parks, Boulder, CO 80304 \\ ${ }^{3}$ Colorado Native Bird Care and Conservation, Lyons, CO 80540 \\ ${ }^{4}$ Institute for Human-Animal Connection, University of Denver, Denver, CO 80208
}

\begin{abstract}
Aвstract.-The tricolored bat (Perimyotis subflavus) is widely distributed throughout eastern North America. However, this species has also undergone severe population declines in areas where white-nose syndrome has taken hold. Previous records in Colorado showed what appeared to be vagrant individuals with no evidence of established populations. Herein we provide new records for Boulder and Weld Counties, Colorado. We also provide evidence of reproduction supporting the hypothesis of westward expansion of this species. Because the tricolored bat has been significantly impacted by white-nose syndrome in eastern North America, the Rocky Mountain West may provide at least a temporary refugium from this disease.

Resumen.-El murciélago tricolor (Perimyotis subflavus) se distribuye ampliamente a través del este de América del Norte. Sin embargo, en varias ocasiones esta especie ha experimentado una disminución de sus poblaciones en áreas donde se ha establecido el síndrome de la nariz blanca. Registros previos en Colorado reportan individuos nómadas que no mostraron indicio de pertenecer a poblaciones establecidas. En el presente estudio, proporcionamos nuevos registros de esta especie en los condados de Boulder y Weld, Colorado. También, aportamos evidencia de reproducción, apoyando la hipótesis de expansión de esta especie hacia el oeste. Debido a que, el murciélago tricolor ha sido muy afectado por el síndrome de la nariz blanca en el este de América del Norte, el oeste de la cordillera Rocky Mountain podría proporcionar, por lo menos, un refugio temporal contra esta enfermedad.
\end{abstract}

The tricolored bat (Perimyotis subflavus), previously known as the eastern pipistrelle (Pipistrellus subflavus) (Hoofer et al. 2006), is widely distributed throughout eastern North America from Florida to Nova Scotia, extending westward into Minnesota, Kansas, and Texas, and southward into Mexico, Guatemala, and Honduras (Hall 1981). This species roosts by hanging from the branches of deciduous trees but is also known to roost in human dwellings or within rock crevices. During the summer months, tricolored bats are typically found roosting and foraging in riparian habitats that border rivers and streams (Humphrey 1975, Humphrey et al. 1976). Hibernacula include caves, mines, buildings, and other human-made structures (see review in Fujita and Kunz 1984). On 16 June 2016, P. subflavus was petitioned for federal protection as a threatened species in response to significant population declines throughout parts of its range. These declines are caused predominantly by an epizootic disease called white-nose syndrome, caused by an invasive European fungus, Pseudogymnoascus destructans (Puechmaille et al. 2011).

Tricolored bats have been documented in western states over the last few decades, and the species is suspected to be undertaking a significant western range expansion (Geluso et al. 2005, White et al. 2006, Geluso and Mink 2009, Valdez et al. 2009). Observations of this species overwintering at hibernacula in South Dakota, New Mexico, and Texas strongly indicate that these individuals are yearly residents in these states (Geluso et al. 2005). However, no evidence that reproductive populations have been established in the West was available until now. Herein we report on new records from Boulder and Weld

*Corresponding author: rick.adams@unco.edu

orcid.org/0000-0002-0119-5052 


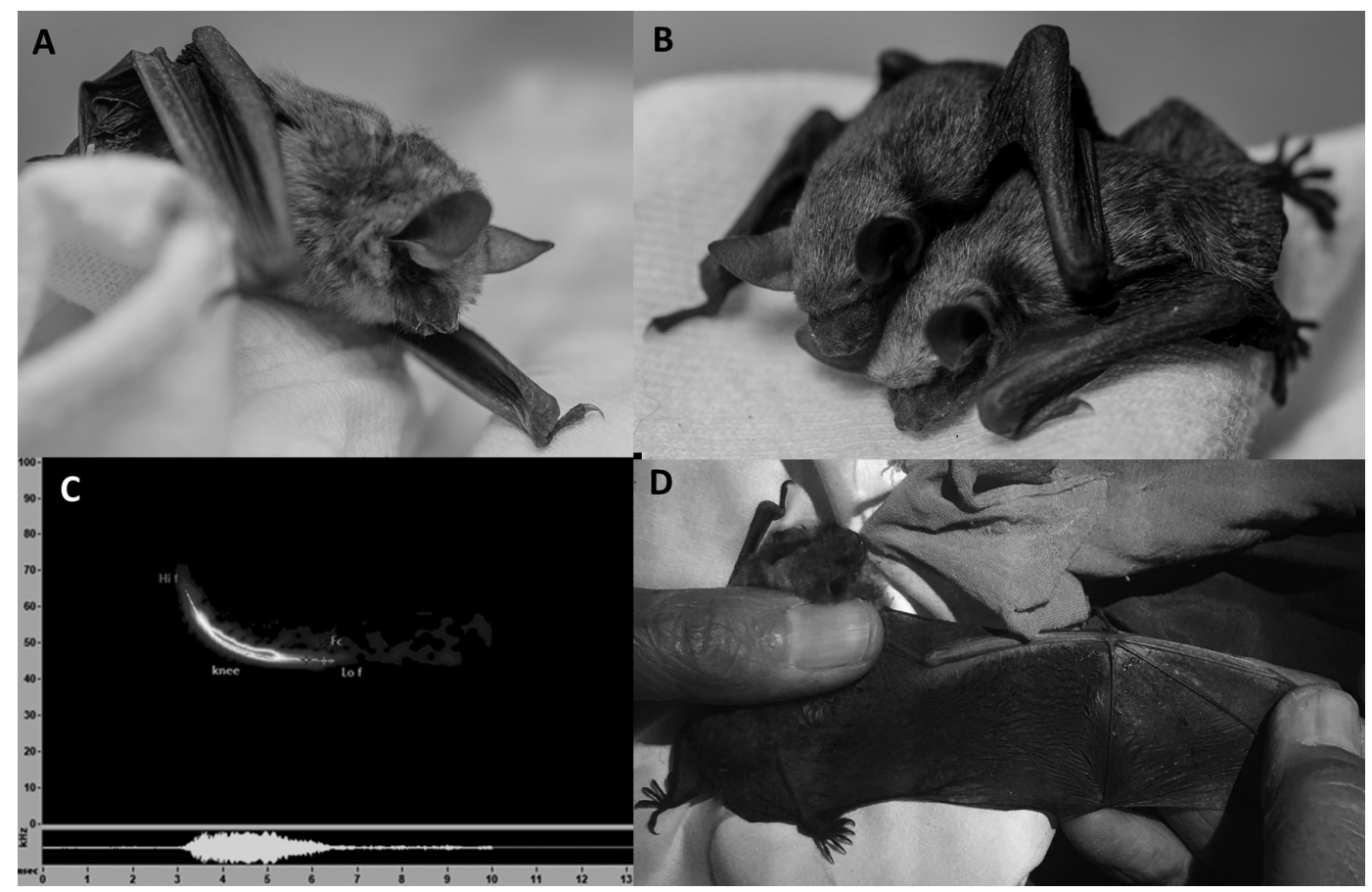

Fig. 1. A and B, Female Perimyotis subflavus with twins (not to scale) from South Boulder Creek, July 2017, Boulder County, Colorado (image (C) Donna Nespoli, used with permission); C, Representative sonogram of P. subflavus recorded along South Boulder Creek; D, Adult female P. subflavus captured with a mist net while foraging along South Boulder Creek on 3 September 2017 (image courtesy of Morgan Stoner).

Counties that include the discovery of a lactating female with twins.

The first record of $P$. subflavus in Colorado was a female discovered on the side of a dwelling in September 1987 (Fitzgerald et al. 1989) in Greeley, Weld County. Armstrong et al. (2006) reported a deceased nonreproductive female found in Boulder, Boulder County, on 30 March 2004. The authors surmised that this individual likely had hibernated in the area. On 8 September 2013, we observed a deceased, nonscrotal male P. subflavus (length of forearm $31.9 \mathrm{~mm}$, mass $6.6 \mathrm{~g}$ ) along a small stream in a wildlife protection area called Twin Lakes $\left(40^{\circ} 3.770^{\prime} \mathrm{N}, 105^{\circ} 11.608^{\prime} \mathrm{W}\right.$, elevation $1580 \mathrm{~m}$ ) in eastern Boulder County. On 7 July 2017, a lactating female P. subflavus (length of forearm $31.5 \mathrm{~mm}$, mass $4.6 \mathrm{~g}$ ) with twins fell from a tree being pruned near South Boulder Creek, Boulder County $\left(40^{\circ} 0.391^{\prime} \mathrm{N}\right.$, $105^{\circ} 13.567^{\prime} \mathrm{W}$, elevation $1605 \mathrm{~m}$; Fig. 1A, 1B). The mother and one of the young were deposited in the University of Northern Colorado natural history collections.
On 22 August 2017, we deployed a SM2+BAT sonar detector (Wildlife Acoustics Inc., Maynard, MA) along South Boulder Creek near where the female with twins was recovered. Over 10 nights (22-31 August 2017), the detector recorded 707 sonar sequences identified as $P$. subflavus (Fig. 1C) by SonoBat 3.1 call analysis software (SonoBat Inc., Arcata, CA). In addition, 49 call sequences were identified as the small-footed myotis (Myotis ciliolabrum), 8 were little brown myotis (M. lucifugus), and 2 were longeared myotis (M. evotis). On 3 September 2017, we ran a 6-m mist net (Avinet Inc., Portland, ME) across South Boulder Creek (Fig. 2) and captured a single foraging female P. subflavus (length of forearm $31.8 \mathrm{~mm}$, mass $4.7 \mathrm{~g})$ that was neither lactating nor pregnant. In addition, on 1 October 2017 we recovered a male P. subflavus (length of forearm 32.1 $\mathrm{mm}$, mass $6.5 \mathrm{~g}$ ) from Berthoud in Weld County (Fig. 2). After we made sure the individual was in good health, he was released 2 days later at the site. 


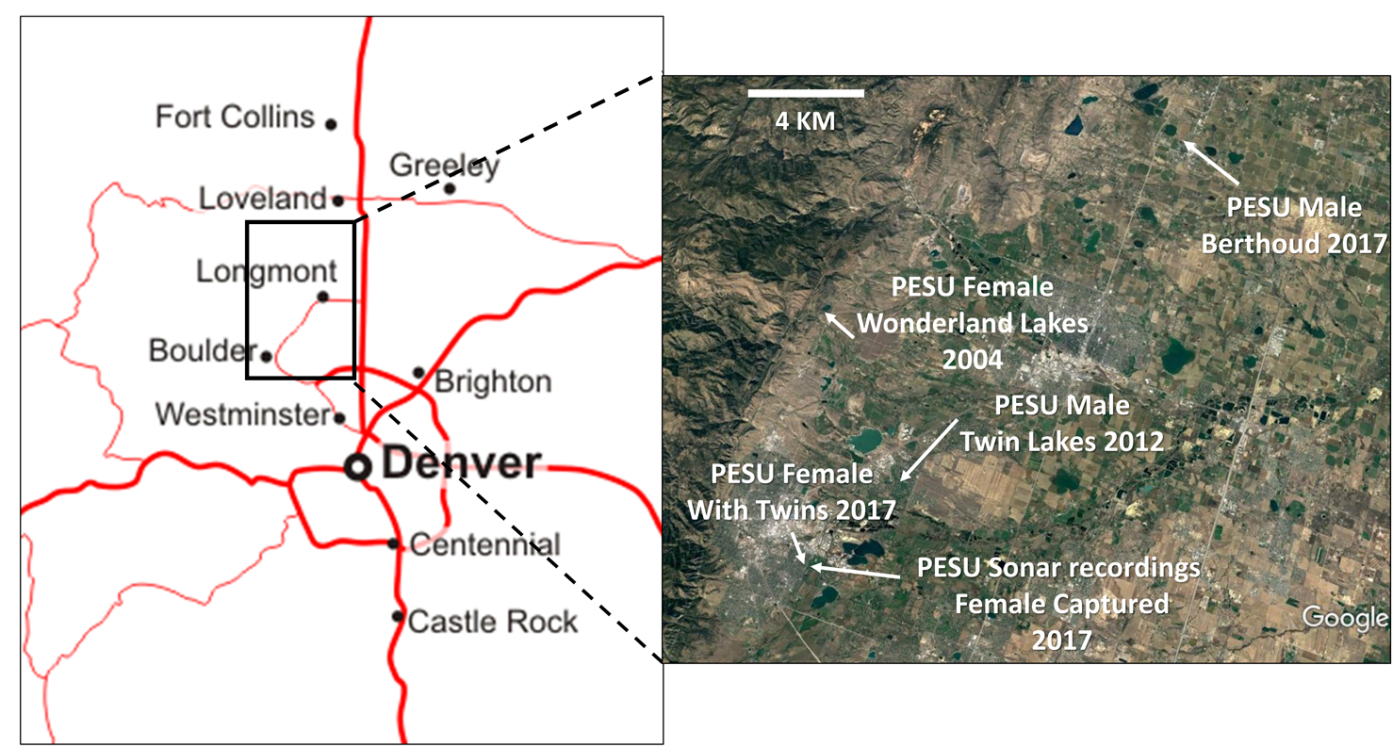

Fig. 2. Map showing area where Perimyotis subflavus was found along the Front Range in Colorado in 2012 and 2017. Inset shows specific localities, including a 2004 record from Armstrong et al. (2006). The 2017 record from Berthoud was in Weld County; all other records were in Boulder County.

Records provided in this paper add to the growing evidence that $P$. subflavus is moving westward and establishing reproductive populations (Adams 2003, Geluso et al. 2005, Armstrong et al. 2006). The areas in which $P$. subflavus has been discovered in Boulder and Weld Counties are proximal to the South Platte River, a major tributary of the Platte River in Nebraska, which forms a drainage basin in the Colorado Front Range. The riparian system along the Platte and South Platte Rivers would likely provide an east-west movement corridor for P. subflavus across the Great Plains, affording an opportunity to establish founder populations in eastern Colorado and along the Front Range foothills. One would surmise that the Continental Divide will be a significant barrier to further westward range expansions for this species in Colorado. Establishment of reproductive colonies in the Rocky Mountain West might be significant for the long-term survival of this species because the region has so far avoided white-nose syndrome, which has devastated many bat colonies in North America (Turner et al. 2011).

\section{ACKNOWLEDGMENTS}

We thank the City of Boulder Open Space and Mountain Parks, the Boulder County
Parks and Open Space Department (OSMP), the University of Northern Colorado, and Colorado Native Bird Care and Conservation for help with this project.

\section{Literature Cited}

ADAMS, R.A. 2003. Bats of the Rocky Mountain West: natural history, ecology, and conservation. University Press of Colorado, Niwot, CO.

Armstrong, D.M., R.A. Adams, and K.E. Taylor. 2006. New records of the eastern pipistrelle (Pipistrellus subflavus) in Colorado. Western North American Naturalist 66:268-269.

Fitzgerald, J.P., D. Taylor, and M. Prendergast. 1989. New records of bats from northeastern Colorado. Journal of the Colorado-Wyoming Academy of Science 21:22.

Fujita, M.S., AND T.H. Kunz. 1984. Pipistrellus subflavus. Mammalian Species No. 228. American Society of Mammalogists.

Geluso, K., AND J.N. Mink. 2009. Use of bridges by bats (Mammalia: Chiroptera) in the Rio Grand Valley, New Mexico. Southwestern Naturalist 54: 421-429.

Geluso, K., T.R. Mollhagan, J.M. Tigner, and M.A. BOGAN. 2005. Westward expansion of the eastern pipistrelle (Pipistrellus subflavus) in the United States, including new records from New Mexico, South Dakota, and Texas. Western North American Naturalist 65:405-409.

HaLl, E.R. 1981. The mammals of North America. 2nd edition. John Wiley \& Sons, New York, NY.

Hoofer, S.R., R.A. Van Den Bussche, and I. Horáček. 2006. Generic status of the American pipistrelles 
(Vespertilionidae) with description of a new genus. Journal of Mammalogy 87:981-992.

Humphrey, S.R. 1975. Nursery roosts and community diversity of Nearctic bats. Journal of Mammalogy 56:321-346.

Humphrey, S.R., R.K. Laval, and R.L. Clawson. 1976. Nursey populations of Pipistrellus subflavus (Chiroptera: Vespertilionidae) in Missouri. Transactions of the Illinois State Academy of Sciences 69:367.

Puechmaille, S.J., G. Wibbelt, V. Korn, H. Fuller, F Forget, K. Mühldorfer, A. Kurth, W. BogdanowICZ, C. Borel, T. Bosch, ET AL. 2011. Pan-European distribution of white-nose syndrome fungus (Geomyces destructans) not associated with mass mortality. PLOS ONE 6:e19167.

Turner, G.G., D.M. Reeder, and J.T.H. Coleman. 2011.

A five-year assessment of mortality and geographic spread of white-nose syndrome in North American bats and a look to the future. Bat Research News $52: 13-27$.

Valdez, E.W., J. Foote, G. Allison-Kosior, and D.M. RoEMER. 2009. Spring and winter records of the eastern pipistrelle (Perimyotis subflavus) in southwestern New Mexico. Western North American Naturalist 69:396-398.

White, J.A., P.R. Moosman JR., C.H. Kilgore, and T.I. BEST. 2006. First record of the eastern pipistrelle (Pipistrellus subflavus) from southern New Mexico. Southwestern Naturalist 51:420-422.

Received 18 December 2017 Revised 24 February 2018

Accepted 14 March 2018

Published online 3 July 2018 